\title{
Macrothink
}

\section{Using Students' Evaluation in Improving Teaching Effectiveness}

\author{
Adel Mahmoud Al Samman (Corresponding author) \\ Dept. of Bus. Administration, Applied Science University \\ PO Box 5055, East Eker, Bahrain \\ Tel: 973-338-21-339Ｅ-mail: adel.alsamman@asu.edu.bh
}

Faiza Zitouni

Dept. of Bus. Administration, Applied Science University

PO Box 5055, East Eker, Bahrain

\author{
Received: January 1, 2018 Accepted: January 16, 2018 Published: January 25, 2018 \\ doi:10.5296/ijld.v8i1.12393 URL: https://doi.org/10.5296/ijld.v8i1.12393
}

\begin{abstract}
By all means, teachers need the evaluation and feedback of their students to know how they are doing and whether their efforts are fruitful or going the wrong direction. Consulting with students and exploring their perspective of the proficiency of their teachers could be the most efficient method to develop and enhance the teaching efficiency. This paper aims at probing to what extent the academic members in Applied Science University possess the professional competencies required, as per the students' perspective. We chose the most important four dimensions of core competencies associated with teaching in higher education, namely professional, technological, humane, and assessment. A designed survey shall be developed and distributed among a representative sample of students. The analysis of which will show the availability level of such competencies, and any missing ones, from the students' perspective. Qualitative data will also be gathered through structured interviews with the Deanship of Student Affairs and the Students Council members. In the light of the paper's findings, a conceptual framework will be developed and a set of recommendations will be submitted to the top management of the university in order to be considered in the future academic hiring process, and the development programs of the current academic staff aiming at improving the teaching process efficiency.
\end{abstract}

Keywords: Higher education, student evaluation, professional attributes, students' perspective, teaching. 


\section{Introduction}

"Higher education is a dynamic enterprise facing unprecedented change" (ACPA, NASPA, 2015). Just like most of the concepts in modern world, it encounters both, opportunities and challenges. Of the opportunities, we have the higher demand for access to higher education with the mounting number of applicants each year, the increasing demographic and nondemographic diversity, especially in modern time Arab world with the tendency to educate more women, and the special care directed towards individuals with special needs, the technological innovations with its impact on the teaching/ learning strategies and pedagogies and the process delivery systems, and the shift that occurred to the students' learning experience moving from the traditional spoon feeding approach, to the modern ones that enabled more interactions from students and their increasing role in the learning process.

Among the significant challenges higher education encounters in our area are its increasing costs compared to the average income, the higher expectations of employers, the mismatch that happens sometimes between the graduate attributes and the labor market demands, and the quality of faculty preparation and core competencies that sometimes are not the right ones for message delivery.

Hiring of higher education faculties in the middle -east in general is subject to various conditions. In some countries the process is a routine one getting the graduates' top of class students, in some others, it is subject to certain criteria established by the governmental body responsible for the higher education, and in some countries, educational institutes management get to establish their own criteria and competencies for which the newly hired faculties should possess in order to pursue their career with such institutes.

Faculty core competencies is one of the main reasons for the difficulties we encounter with higher education in the middle- east in general, and in the Arab world in particular. In most of the above mentioned procedures adopted by higher education institutions in selecting their faculties, we rarely hear about the perspective of those who are most concerned with faculty competencies and attributes, namely students.

Even though we find in some higher education institutions some surveys asking their opinions about their learning experience within such institutions, most of students in fact deal with such surveys as a routine thing they have to take in order to get to the following step in this procedure.

There are some questions about how convinced the top management and faculties of such institutions about the ability of students to realize and evaluate their teachers' strengths and weaknesses and how to separate them from each other, and how efficient students' perspective is in developing and enhancing the professional core competencies of faculty members,

This document is intended to set out the scope and content of professional competencies required, from the students' perspective, in their faculty members at ASU, as one of the higher education institutions in the Kingdom of Bahrain, to outline the strengths and weakness of faculty members in four of the teaching process key areas of professional 
competencies, namely professional, technological, humane, and assessment/ evaluation competencies. The main aim of this process is to set a conceptual framework and a set of recommendations to be submitted to the top management of the university in order to be considered in the future academic hiring process, and the development programs of the current academic staff.

\section{Theoretical Review}

Higher education is a source of pride in the western civilization for anyone concerned with it (Jamil Salmi, 2015). Leaders of higher education in these countries claim that their countries were the cradle of the most ancient universities in the modern time. Oxford was established in 1167 and the French Sorbonne in 1160. In spite of these claims, it was proven by historians that the most ancient, and still operative, university in the whole world is the University of Al Quaraouiyine in Fez, Morocco that was established in 859. Contributions of the Arab universities should be a source of pride for the Arab world represented by its ancient universities such as Zitouna in Tunisia, Al Nezamia in Iraq, and Al Azhar in Cairo, in addition to role played by the Cairo university that was established in 1908 under the name of the Egyptian University, that was the minaret for many Arab intellectuals during the 20th century (Jamil Salmi, 2015).

In spite if this, higher education in the Arab world nowadays encounters several challenges. In the meantime our countries witness a substantial increase in number of educational institutions and students, quality and content of education are still sources of concern (Jamil Salmi, 2015). In many cases, weak selection and insufficient resources led to excessive congestion in the educational facilities that made it unsuitable for the delivery of its main mission. Most universities in our countries depend on traditional syllabi and outdated educational practices. This led to a high rate of drop out that sometimes reach $50 \%$ of students. In addition, the mismatch between the graduate attributes and the requirements of the labor market in most of our countries led to a high rate. According the Economist, "In 2010, on the eve of the Arab uprisings, total and youth unemployment rates in the Arab world were already the highest of any region, at $10 \%$ and $27 \%$ respectively. Since then these Figures have risen further, to nearly $12 \%$ and $30 \%$. Amazingly, in some Arab countries, the more time you spend in school, the less chance you have of finding a job. In Egypt 34\% of university graduates were unemployed in 2014 , compared with $2 \%$ of those with less than a primary education" (The Economist, 2016).

It is apparent then that the role of higher education institutions needs to be modified in order to suit current international developments, with its various political, economic and social dimensions (Al-rashdan, 2010). Most of the Arab universities adopt traditional education based on rote memorization of material without enabling students to be innovative and mix scientific knowledge with practical application. Students are not encouraged to take a critical, analytical approach towards numerous problems in society, creating a spirit of student submissiveness and fear to voice their opinion (Al-rashdan, 2010).

Engaging students and staff effectively as partners in learning and teaching is arguably one of the most important issues facing higher education in the 21 st century. Students as partners is a 
concept which interweaves through many other debates, including assessment and feedback, employability, flexible pedagogies, internationalization, linking teaching and research, and retention and success (Healey et al., 2014).

Students need not be silent in the improvement of reaching in higher education. In actively seeking students' response to instruction, college, and universities are sending the important message that they honor and support the teaching- learning process (Gordon, ). According to North Carolina State University Handbook for Advising and Teaching (1994), student evaluation of teacher effectiveness serves two purposes, providing instructor with important feedback from the consumer's point of view, and providing administrators and department chairs in assessing perceived effectiveness of instruction (NC State University, 1994).

Faculties remain the effective human means for transferring and facilitating of all kinds of expertise to students (Radouan, 2014). Passion for knowledge cannot be implanted effectively in students without the human medium and the personal rapport represented in the teacher (Radouan, 2014).

It also became evident that for those that participated in a partnership approach it can lead to more motivated learners and enthused academic staff. Students talked about the breaking down of barriers and how they experienced a better classroom experience (Curran, 2015).

There are plentiful literature on the importance of measuring and developing faculty core competencies in the Arab world universities. Ben Bateel (2010), Al Hakami (2004), Al Khateeb (2006), Momany (2010), Bani Domi (2010), Al Omary (2009) and a lot of other researchers, examined the different required competencies of faculties in different educational institutions in the Arab world from different perspectives.

Having the perspective of students is a very important addition to the different perspectives adopted by other researchers in measuring and developing such competencies. Murray (2005) stated that student rating forms try to do the next best thing by assessing teacher or course characteristics that are 1) believed to contribute to student learning, 2) observable by students, 3 ) widely applicable, and 4) under the control of the instructor, and thus justifiable for use in faculty personnel decision on salary, promotion, and tenure. (Murray, 2005).

But how well do student ratings do in providing a reliable and valid assessment of quality of faculty competencies? Research indicates that student ratings are adequate in terms of reliability, in that ratings of a given instructor are reasonably stable or consistent across courses, years, rating forms, and group of raters (Murray, 2005).

Educators often have mixed feelings about having their students evaluate them. After all, it's inevitable that some students might use the evaluation to "vent" on a more personal level. However, most student feedback can be genuinely helpful, offering teachers a chance for self-awareness and insight that can help then become better at their jobs (Concordia University, 2012).

Feedback is good for students, too, because it helps them feel more fully engaged in their education. Students who feel their opinion matters are far more likely to have a personal stake 
in the educational process.

Feedback also gives teachers concrete advice on making the education process more enjoyable and effective. Educators who are more responsive to their students stand a better chance of providing a quality educational experience (Concordia University, 2012).

\section{Methodology.}

To examine to what extent the academic members in Applied Science University possess the professional competencies required, as per the students' demands, whether such competencies are associated with teaching, technological, humane, or evaluation/ assessment, a practical study was conducted on the university students, with all of its three colleges, Admin. Sciences, Arts and Science, and Law, to come up with findings that would shed the light on this area and help in providing a set of recommendations will be submitted to the top management of the university in order to be considered in the future academic hiring process, and the development programs of the current academic staff.

To develop this questionnaire, the researchers reviewed available literature to expose common ground related to the different areas of competencies that are most convenient with the teaching environment within the university, namely competencies that are associated with teaching, technological, humane, and evaluation/ assessment. A designed survey was developed and distributed, online and manually, among a representative sample of students. Then, a structured interviews was developed and conducted with Deanship of Student Affairs and Student Council to gain qualitative data to support the quantitative data gathered from the questionnaire.

\subsection{Sample Size}

Due to the vast study population, represented in all students within the university, a convenient sample of 250 students was chosen to test to what extent the academic members in Applied Science University possess the professional competencies required. The valid questionnaires analyzed was 184 , with the response rate of $72 \%$. Sample size should have been more than this, but due to the short time of the summer semester, and the necessity to gather the required information after the mid-semester exams, researchers were working under a tight timeframe that should be considered in future studies.

Apart from demographic variables, all others statements were measured using Likert type five point scale, where "strongly agree" was given the highest response " 5 " and "strongly disagree" was given the lowest response "1".

\subsection{Data Analysis Technique}

Data was analyzed via the Statistical Package for Social Science (SPSS), to get such statistical tools such as means, simple regression, Pearson correlation, and standard deviation.

\subsection{Tested Hypotheses}

H1: ASU academic members practice the Professional Competencies from the students' perspective. 


\section{Macrothink}

To empirically test it, a set of indicators were chosen, to include:

- Mastering the Specialty Subject.

- Illustration and analyzing lesson contents.

- Employment of expertise and student support.

- Awareness of the proper teaching strategies and methodologies.

- Motivating of students.

H2: ASU academic members practice the Technological Competencies from the students' perspective.

To empirically test it, a set of indicators were chosen, to include:

- Employment of electronic teaching means.

- Urging students to use online sources and references.

- Employment of technological software and applications.

H3: ASU academic members practice the Humane Competencies from the students' perspective.

To empirically test it, a set of indicators were chosen, to include:

- Encouraging an atmosphere of democracy within class.

- Adoption of respect and fairness with students.

- Avoiding sarcasm and underestimation with students.

- Providing a proper teaching/ learning environment to students.

H4: ASU academic members practice the Evaluation/ Assessment Competencies from the students' perspective.

To empirically test it, a set of indicators were chosen, to include:

- Consideration of individual differences in assessment.

- Seeking of justice in assessment.

- Employment of various evaluation/ assessment means.

- Equipping students with sufficient knowledge and psychologically preparing them for exams.

\section{Statistics and Discussion}

This part of the paper represents the statistical data of the survey conducted at the designated case study; the Applied Science University, in the Kingdom of Bahrain with the main aim is to study the core competencies of a 'Good Lecturer' from the perspective of students. The primary data collection was based on quantitative research method where survey questionnaires were randomly distributed amongst students at the University of about 3000 total Number of students, from three existing colleges (i.e. the college of administrative sciences, the college law and the college of arts and science).

The selected descriptive variables were as follows; (i) student gender, (ii) student employment status, (iii) student age that varies between 17 -20 years, 21-24 years, 25-29 
years, above 30 years and, (iv) student study period at the University that varies between $0-1$ year, 1- 2 years, 2-3 years, 3-4 yeas, above 4 years.

A set of dependent variables were selected from the undertaken literature review as listed in table 1, and clustered into four themes that describe the core competencies of a good lecturer as follows; (1) professional competencies, (2) the use of technology competencies, (3) the humane competencies, (4) assessment and evaluation Competencies.

The number of participants that completed the questionnaires was 184 out of 250 distributed, reaching $72 \%$ response rate. The participants who are mostly students were offered the choice of 5 pre-coded responses using Likert scale, giving them the choice to select one option, and express their opinions in how much they agree or disagree with the variable statements, with the option to neutral point where students neither agree nor disagree. The survey was carried out in summer of the academic year 2016-2017.

The results of the averages as presented in the table 2 and in the schematic representations from graphs Q6 to Q33 show that most students either agreed or neither agreed nor disagreed on the listed statements presented in the questionnaire survey of this study, furthermore most of the trends are inclined towards significant agreements.

In other words and in general, the results of the study show no significant conflicts of opinions from the core competencies of a good lecture as selected by the authors in the presented questionnaire survey and the students' opinions.

A correlation between the variables was also carried out and the results show that; (a) there is no correlation between the number of years the students spent at the University and his/or her change of view on the core competencies of a good lecturer (refer to graphs Q6-Q33). (b) There was a negative significant correlation between the age of the student and statements Q13, Q14, Q15 at the levels 0.01, 0.05 and 0.01 respectively which fall within the core technology competencies. This indicates that older students believe that technology and eLearning are not the competencies used by the lecturers. (c) There was a negative significant correlation between the gender of the student and the statements Q9 and Q10, where male and female students disagree on the lecturer enthusiasm and motivation expertise in keeping them focus and increasing their knowledge. (d) There was a positive significant correlation between the colleges and the statements Q12, Q25 and Q30, where students from the same college agree that the core competencies for a good lecturer are in encouraging students to use more critical thinking, research, in creating a sense of humor in class, and in providing formative and summative assessment and feedback. 


\section{Macrothink}

Table 1. List of clustered variables

\section{Part A: Professional Competencies}

Q6 Academic members are good followers of updates related to his/her discipline.

Q7 Academic members are good managers of the educational session in class.

Q8 Academic members use the proper tools to deliver his/her ideas.

Q9 Academic members are always enthusiastic about motivating students and keeping them focus.

Q10 Academic members employ their expertise and studies to increase the student's knowledge.

Q11 Academic members urge students to use their own perspectives and points of view.

Q12 Academic members urge students to use their critical thinking and research in education resources.

Part B: Use of Technology competencies

Q13 Academic members employ the e-learning facility in teaching.

Q14 Academic members urge students about the importance of e-learning.

Q15 Academic members use internet resources as a means of scientific research and a source for knowledge.

Q16 Academic members use technological tools in delivering course content.

Q17 Academic members urge students about using online books, research, and references in their assignments.

Q18 Academic members use university portal and other online means in communicating with students.

Q19 Academic members use the different computer software, such as word, excel, PowerPoint, etc. in preparing for lessons.

\section{Part C: Humane Competencies}

Q20 Academic members circulate a democratic atmosphere within lectures.

Q21 Academic members urge students to express their points of view freely.

Q22 Academic members accept and embrace students' points of view, even if they contradict with theirs.

Q23 Academic members treat students with fairness and respect.

Q24 Academic members avoid being sarcastic with students.

Q25 Academic members circulate a sense of humor and urges them to like lectures

Q26 Academic members promote the necessary values, attitudes, and ethics for students.

\section{Part D: Assessment and Evaluation competencies}

Q27 Exam questions are varied in difficulty levels

Q28 Academic members prepare students, from the psychological and knowledge perspective, for exams

Q29 Academic members are accurate and fair when assessing summative works

Q30 Academic members use informative and summative assessment

Q31 Academic members follows up activities and assignments, and assigns weight for each one

Q32 Academic members are keen on providing feedback for conducted works

Q33 Academic members are keen on using the feedback he/she receives from students 


\section{MInstitute Macrothink}
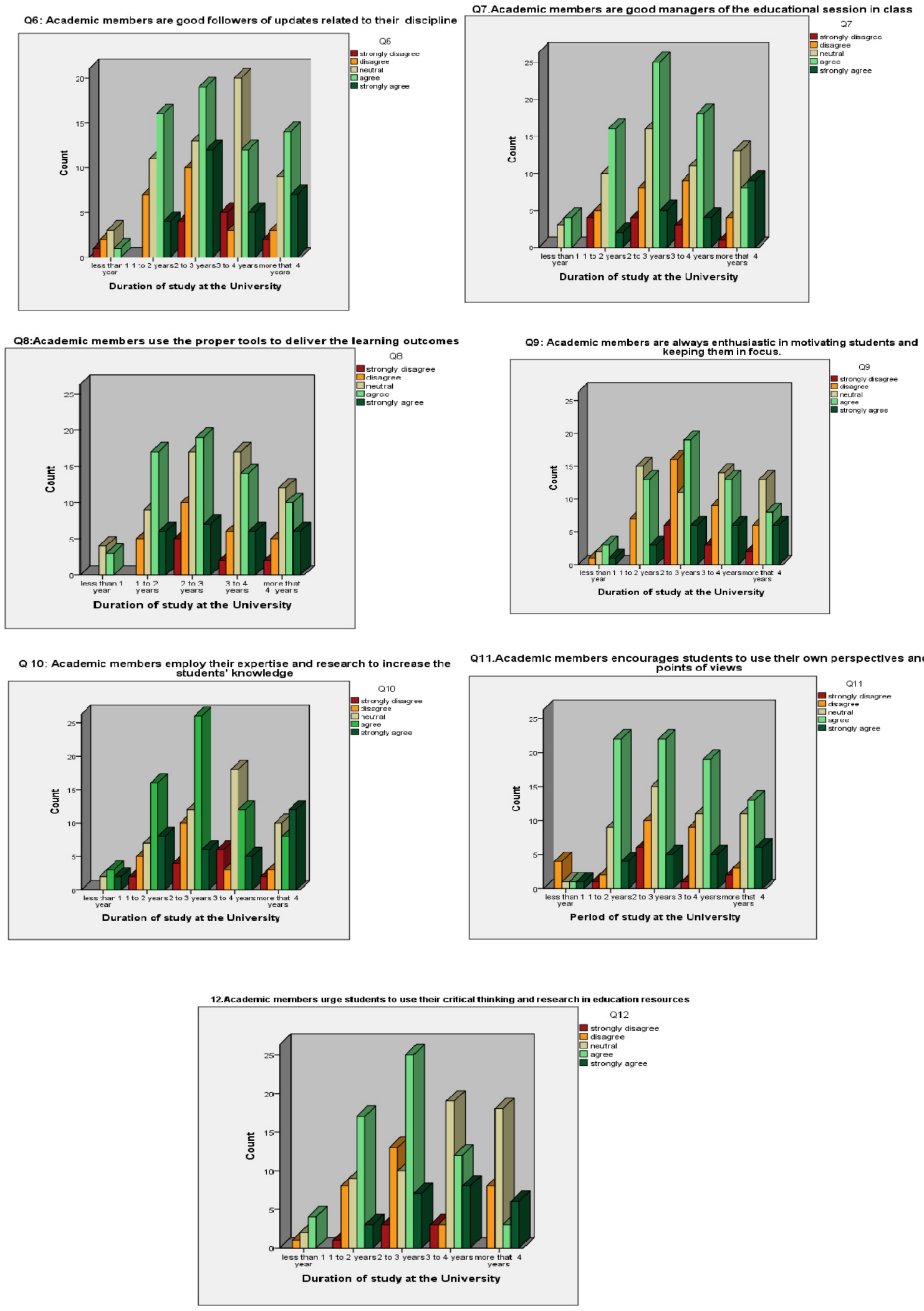

Figure 1. Professional Competencies

The results as per Figure 1 on the professional competencies show that most students agree to strongly agree with the suggested academics' professional competencies in 


\section{Macrothink}

International Journal of Learning and Development

ISSN 2164-4063 2018, Vol. 8, No. 1

following their updates related to their subject discipline, in managing their educational class session, in using proper tools to deliver their ideas, in using their expertise and research studies to increase students' knowledge. Students regardless their gender, age, employment status, duration at the university and college, they all agree to strongly agree that academics urge students to use their own perspectives, points of views and to use their critical thinking and research in education resources. Students also agree to strongly agree that academics are always enthusiastic about motivating them and in keeping them focus during class.
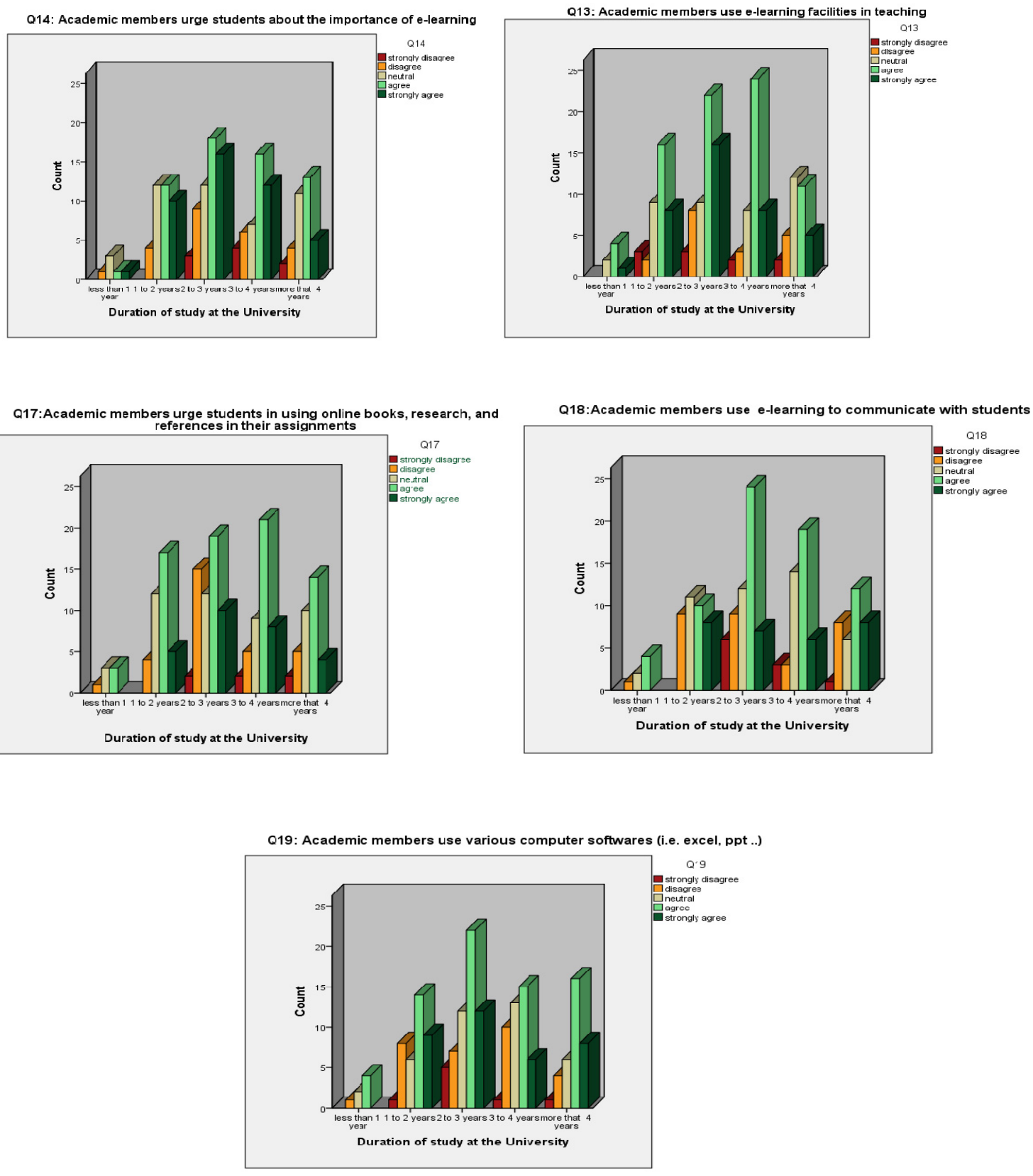

Figure 2. Use of Technology

Results on the use of Technology competencies show that most students across the university in all colleges agree that academic employ the e-learning facility in teaching and internet 


\section{Macrothink}

International Journal of Learning and Development ISSN 2164-4063 2018, Vol. 8, No. 1

resources and they highlight to students the importance of e-learning facilities within the University.
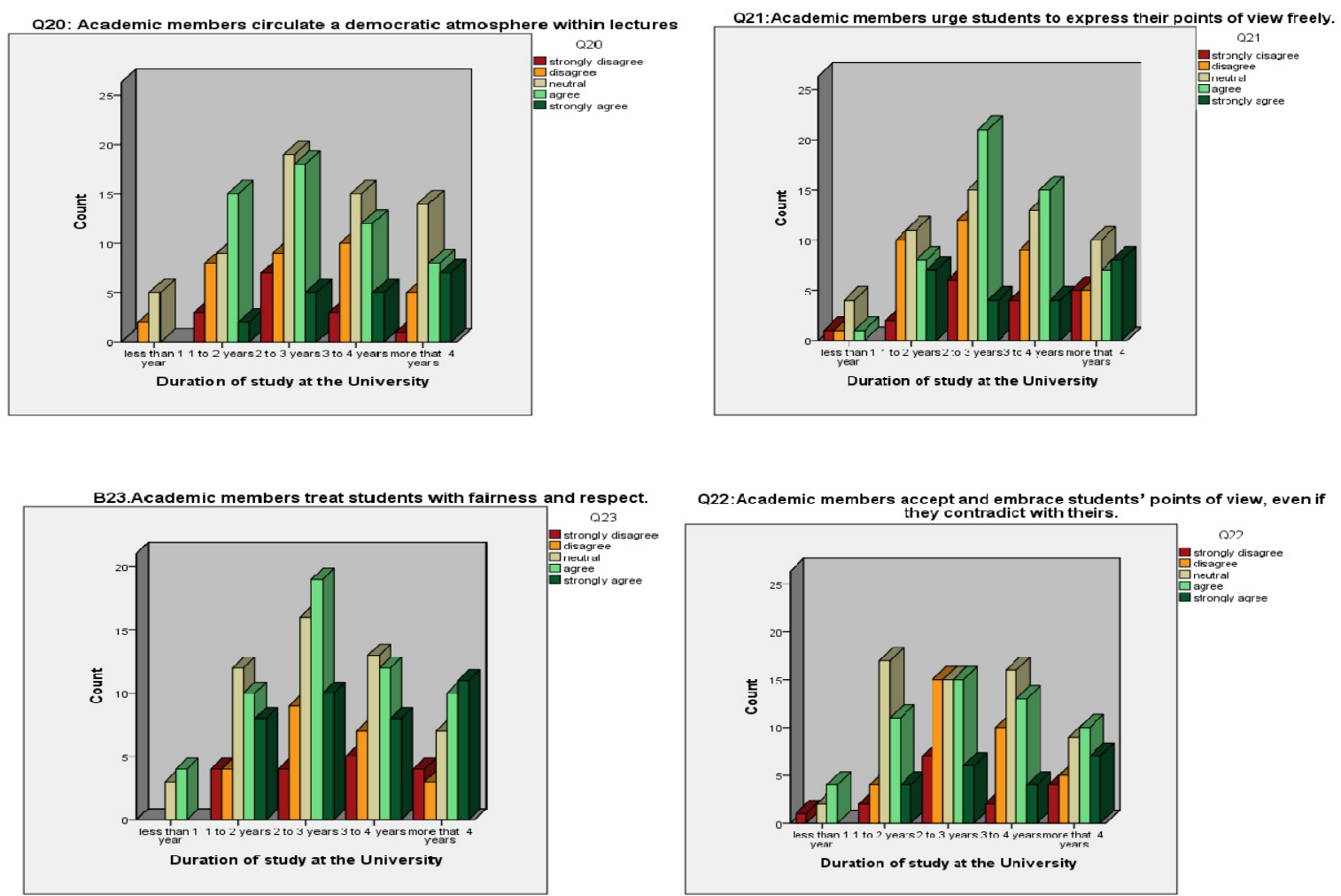

Q25:Academic members bring a sense of humor for enjoyable lectures
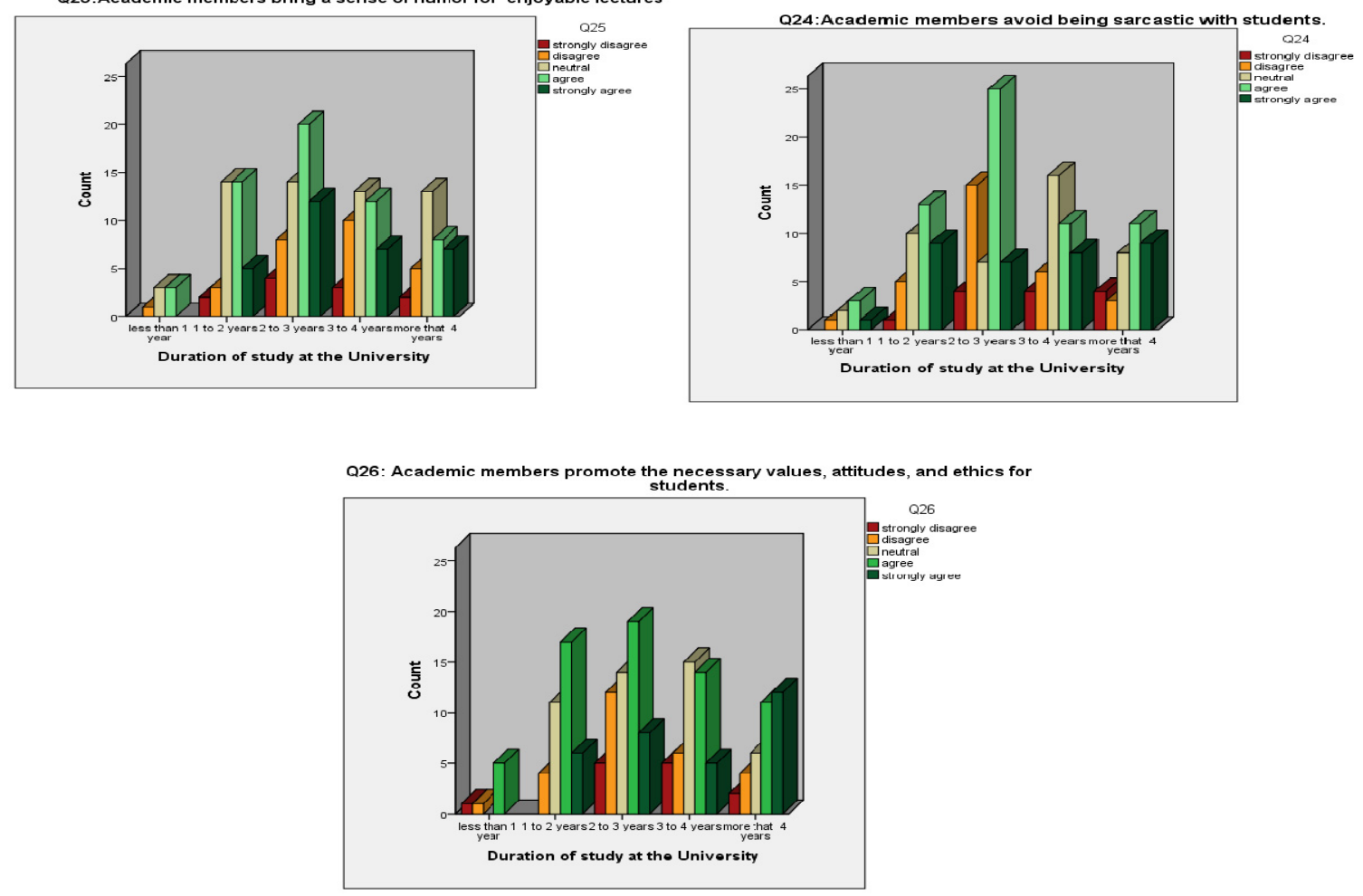

Figure 3. Human Competencies 


\section{Ml Macrothink}

International Journal of Learning and Development

ISSN 2164-4063

2018, Vol. 8, No. 1

The results on the academics Humane Competencies show that students somewhat from impartial to agree over their opinions regarding academics in creating a democratic atmosphere in class, and in encouraging students to do so. The results show the same trend, but more towards agree and strongly agree in their opinions regarding academics treating them fairly, avoiding sarcasm in class, and in creating a sense of humor and the necessary ethical values. The trend tends to be similar across the colleges regardless of age, gender or employment status.
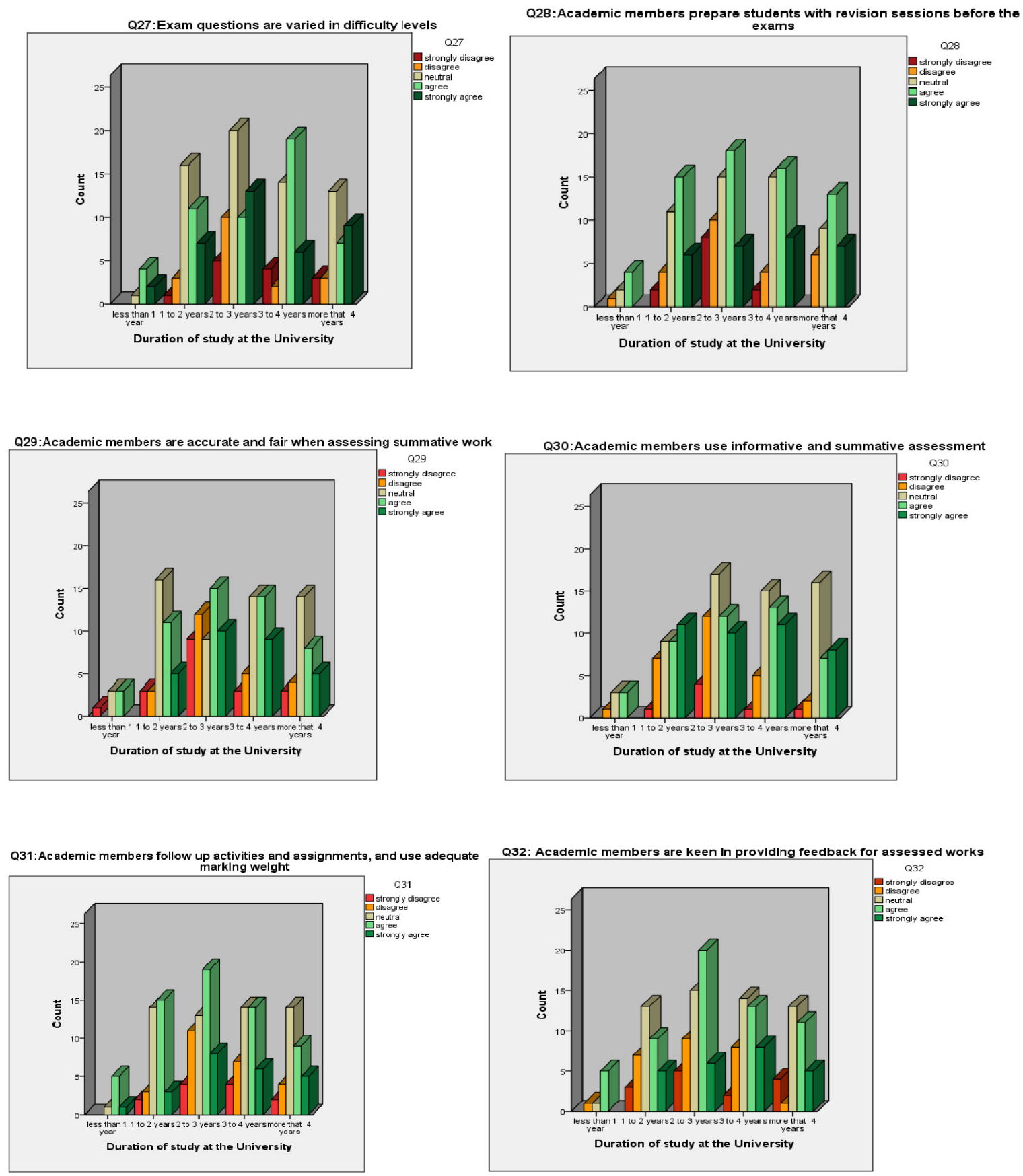

Figure 4. Assessment and Evaluation 


\section{Macrothink}

The results on assessment and evaluation competencies show similar trends from partial to agree opinions between students regarding the academics that vary their exams questions in difficulty levels also most students agree that academics use formative and summative assessment and they are accurate and fair in their assessments. Students agree that academic staff are keen in providing feedback on students work.

Most of the results show positive feedback on academics competencies and this trend is across the colleges regardless their gender, age, the employment status and their duration of education at the University.

\section{Implications and Conclusion}

The researchers had to accommodate themselves with such limitations, to include but not limited to, the relatively small sample size in relation to the study population and the time restrictions of the summer semester, in addition to the response rate of the sample individuals.

Findings of the data analysis and the conducted interviews revealed interesting things. Not even one statement received close to 4 in the total average. It means that this process, in spite of the mentioned limitations, does not go in line to some extent with other evaluation processes conducted within the university.

There are some related variables in the faculty evaluation process, such as the diversity of student characteristics, faculty objectives and the different teaching methods, in addition to the institutional contexts. These variables should be considered as an integrated process when developing the evaluation process.

As outlined in this paper, student opinion continues to be a major factor in the evaluation of teacher effectiveness at institutions of higher education. But, students' assessment of their teachers is only one component of an important process. Therefore, it becomes reasonable to expect students to make an important input to the system and it is imperative that teachers be receptive to student feedback. However, there is no one correct method of teaching (Joyce \& Weil, 1996).

As Seldin and Angelo (1997) warned regarding the development and administration of student evaluations that "the entire evaluation system, including any rating forms, should be designed to meet a specific set of specific purposes and needs and should have a clear connection to the academic rewards system". Therefore, student evaluation of teachers should be integrated with other steps of the evaluation process to come up with a unified scheme outlining strengths and weaknesses of faculties and to rely on in making development plans. In addition, this process should be revised regularly and compared within time intervals to make sure we are on the right track.

Recommendations include adopting the framework of the higher education academy (HEA) with its five areas of the teaching/learning process capabilities to be the basis for the development of the academic staff within the university. Researchers see that the HEA framework is particularly useful in situating partnership working (HEA, 2015). We see the benefits of partnership with students to be mainly located in the learning, teaching and 
assessment and curriculum design and pedagogic consultancy areas of focus and the research output. We recommend starting small and that staff and students engage through partnership through students being welcomed into a discipline community and cast as active participants in their learning. This provides the opportunity for staff and students to develop personally and to build capacity for active learning where student and staff interaction builds trust relationships, which enhances student engagement.

Furthermore, such paper should be followed by a similar work, but with limiting the restrictions, such as conducting the study in the 1 st or 2 nd semester with longer time, and using a wider sample size, and compare results of both studies, in addition to using the five areas of the HEA framework as the basis for the questionnaire used in gathering data and conducting anonymous interviews with students from different colleges and different stages of study to have a comprehensive picture of the students' perspective.

\section{References}

ACPA/ NASPA. (2015). Professional Competency Areas for Student Affairs Educators. ACPA - College Student Educators International \& NASPA. Retrieved 3 August, 2017, from https://www.naspa.org/images/uploads/main/ACPA_NASPA_Professional_Competencies_FI NAL.pdf

Al Hakamy, I. (2004). Required Professional Competencies for Faculties from Students' Perspective and its Relation with Some Variables. Arab Gulf Magazine. Arabic Education Office for Gulf Countries. Edition 90. KSA.

Al Khateeb, A. (2006). University Administration: Modern Studies (1st ed.). Modern Book World. Jordan.

Al Momany, A., \& Khazaaly, Q. (2010). Teaching Competencies for Elementary Teachers in Private Schools in the light of Qualification, Years of Experience, and Specialty Variables (Vol. 26, 3rd ed.). University of Damascus Magazine.

Al Omari, A. (2009). Electronic Teaching Competencies and their Availability to High School Teachers in Makhwaa. Unpublished Master Thesis. Om Al Qura University. KSA.

Al-rashdan, A. (2010). Higher Education in the Arab World: Hopes and Challenges. Retrieved 9 August, 2017, from www.ties-project.eu

Ben Bateel. A. (2010). A Proposed Program Based on the Professional Competencies Necessary for Arabic Language Educators in Aseer Area in the Light of Their Training Needs. Unpublished Master Thesis. King Khaled University. KSA.

Ben Domi, H. (2010). Science Teachers Consideration for Technological Competencies in Enhancing their Professional Performance (Vol. 26, 3rd ed.). University of Damascus Magazine.

Bukari, M. (2015). Exploring the Role of Mentoring in the Quality of Teacher Training in Ghana. International Journal of Learning \& Development. 5(1), 46-67. http://dx.doi.org/10.5296/ijld.v5i1.6822. 


\section{Macrothink}

International Journal of Learning and Development

ISSN 2164-4063

Concordia University (2012). Students Evaluating Teachers: What Educators Need to Know?. Retrieved 25 July, 2017, from http://education.cu-portland.edu/blog/referencematerial/students-evaluating-teachers-what-educators-need-to-know

Daily Char, The Economist. (2016). Youth unemployment in the Arab world: The region's youth is wasting away. Retrieved 31 July, 2017, from, https://www.economist.com/blogs/graphicdetail/2016/08/daily-chart-7

Healy, M., et al. (2014). Engagement through partnership: students as partners in learning and teaching in higher education. HEA.

Islam, T. (2016). Teacher Development Approaches and Strategies in BRAC Nobodhara School. International Journal of Learning \& Development, 6(1), 25-41. https://doi.org/10.5296/ijld.v6i1.8846

Issa, A., and Siddiek, A. (2012). Higher Education in the Arab World \& Challenges of Labor Market. International Journal of Business and Social Science, 3 (9), 146-151.

Malmqvist, J., and Gunnarsson, S. (2008). Faculty Professional Competence Development Programs - Comparing Approaches from three Universities. 4th International CDIO Conference, Hoogeschool Gent, Gent, Belgium.

McCulloch, A. (2009). The student as co-producer: an alternative to the student as consumer metaphor. Studies in Higher Education, 34(2), 171-183.

Murray, H. (2005). Student Evaluation of Teaching: Has It Made a Difference?. Annual Meeting of the Society for Teaching and Learning in Higher Education.

NACE. (2013). Professional Competencies for College and University Career Services Practitioners. National Association of Colleges and Employers.

Obralić, A. (2016). Students' Attitudes towards Acoustics and its Impact on Academic Achievement. International Journal of Learning \& Development, 6(1), 25-41. http://dx.doi.org/10.5296/ ijld.v6i1.8957.

Radwan, B. (2014). Professional Competencies Required for Faculties from Students' Point of View. Unpublished Doctorate Dissertation. Steef University. Algeria.

Salmi, J. (2015). Higher Education in the Arab World: from a Glorious Past to an Ambiguous Future. Retrieved 13 August, 2017, from http://www.wise-qatar.org/higher-education-in-the-arab-world

UNESCO/ EFA. (2014). Technical and Vocational Teachers ᄀand Trainers in the Arab Region: A Review of Policies and Practices on Continuous Professional Development. UNESCO. 


\section{Macrothink}

International Journal of Learning and Development

ISSN 2164-4063

\section{Copyright Disclaimer}

Copyright for this article is retained by the author(s), with first publication rights granted to the journal.

This is an open-access article distributed under the terms and conditions of the Creative Commons Attribution license (http://creativecommons.org/licenses/by/4.0/). 